\title{
Máme se snažit o pozdní otevření infarktové tepny? Konec jedné hypotézy
}

\author{
Vladimír Staněk
}

Jediným racionálním léčebným postupem při vzniku akutního srdečního infarktu s elevacemi úseku ST je časné zprůchodnění infarktové tepny, které vede $\mathrm{k}$ záchraně ischemického myokardu před nekrózou. Údaje $\mathrm{z}$ Globálního registru koronárních príhod ukazují, že zhruba třetina nemocných indikovaných $\mathrm{k}$ reperfuzní léčbě tuto terapii nedostane, at' již pro kontraindikace $\mathrm{k}$ trombolýze nebo pro pozdní pří chod.(1) Ve většině evropských států, stejně jako v USA, totiž na rozdíl od naší země převažuje v léčbě trombolýza nad perkutánní koronární intervenc (PCI). U nemocných, kteři nejsou léčeni reperfuzn léčbou, se najde po odeznění akutní fáze infarktová tepna uzavřená v 80-90 \% případů. U nemocných léčených trombolýzou zůstává po prvních dvou dnech až čtyřech týdnech tepna uzavřená ve $40 \%$. Pouze perkutánní koronární intervence otevře tepnu v 90-95 \%. Kdybychom předpokládali, že ve Spojených státech a v zemích Evropy třetina nemocných není léčena reperfuzí vůbec a $z$ léčených je polovina léčena trombolytikem a druhá polovina koronárni intervencí, pak jednoduchou matematikou dojdeme k závěru, že ze všech nemocných s nefatálním akutním koronárním syndromem s elevacemi úseku ST na elektrokardiogramu má při propuštění $z$ nemocnice zhruba $45 \%$ pacientů uzavřenou infarktovou koronární tepnu. ${ }^{(2,3)}$ Problém se tedy týká velkého okruhu pacientů.

Má se tepna rekanalizovat nebo ne? Tato otázka byla do současnosti diskutována. Někteří se domnívali, že rekanalizace infarktové tepny zmenší riziko pozdější remodelace levé komory, sniží riziko elektrické nestability, zachová možnost kolaterálního oběhu pro prrípad eventuálních dalších příhod v příslušném povodí a zlepší tudíž dlouhodobou prognózu. Tato „late open artery hypothesis“, tedy hypotéza pozdního otevření tepny $\mathrm{v}$ době, kdy již není možná záchrana myokardu, získala řadu zastánců. Jiní byli opačného názoru a argumentovali tím, že perkutánní koronární intervence $\mathrm{v}$ této fázi nese riziko distální embolizace aterotrombotickými hmotami a může spíše uškodit.

Na pozadí těchto diskusí byla koncipována studie OAT (Open Artery Trial), která byla financována grantem amerického Národního ústavu zdraví (NIH). Studie měla testovat zmíněnou hypotézu, tedy že „rutin-

Adresa: prof. MUDr. Vladimír Staněk, CSc., Klinika kardiologie, IKEM, Vídeňská 1958/9, 14021 Praha 4, Česká republika, e-mail: vladimir.stanek@medicon.cz ní rekanalizace tepny s implantací stentu provedená za 3-28 dnů po srdečním infarktu sníží výskyt úmrtí, nefatálního reinfarktu a pokročilého chronického srdečního selhání (NYHA IV)“.

Do studie byli zařazováni nemocní po srdečním infarktu, u kterých angiografie provedená 3-28 dnů po přihodě prokázala uzávěr příslušné koronárnî tepny (TIMI 0 a 1), kteří měli bud'to sníženou ejekční frakci pod $50 \%$ nebo proximální uzávěr tepny nebo obojí. Vylučovacím kritériem bylo srdeční selhávánî (NYHA III-IV), renální insuficience, onemocnění kmene levé věnčité tepny nebo tři tepen, přetrvávající angina a výrazná ischemie při námahovém testu. Námahový test se prováděl pouze tehdy, pokud infarktová zóna nebyla akinetická nebo dyskinetická. Do randomizované studie tedy byli zařazeni pouze stabilizovaní a nekomplikovaní nemocní. Podle tohoto protokolu bylo do studie zahrnuto 2166 nemocných, polovina byla léčena angioplastikou s implantací stentu, u poloviny nebyl výkon proveden. Úspěšnost rekanalizace byla $87 \%$. Doba sledování byla 4 roky.

Dlouho očekávané výsledky byly zveřejněny v prosincovém čísle časopisu New England Journal of Medicine. ${ }^{(4)}$ Závěr je velice stručný. Koronární intervence na uzavřené tepně výskyt úmrtí, reinfarktu a srdečního selhání nesnížila. Navíc u skupiny s koronární intervencí byl zaznamenán trend $\mathrm{k}$ většímu výskytu reinfarktů $(6,9$ a 5,0 \%,p=0,08).

Při zamyšlení nad těmito výsledky nás napadají některé otázky. Zůstává tepna po rekanalizaci skutečně dlouhodobě otevřená? U podskupiny 381 pacientů $^{(5)}$ byla za rok provedena kontrolní angiografie, která ukázala průchodnost intervenované tepny v $83 \%$. Nerekanalizuje se později neintervenovaná tepna spontánně? Kontrolní angiografie provedená u zmíněné podskupiny ukázala pozdèjší spontánní rekanalizaci u neintervenovaných jen ve $25 \%$ případů. Má pozdní rekanalizace alespoň příznivý vliv na ejekční frakci levé komory? Výsledky této za rok provedené kontrolní angiografické studie ukázaly, že nikoliv. Další otázkou je, zda rekanalizace vůbec může zlepšit perfuzi periinfarktové oblasti. U podskupiny 124 nemocných byla provedena pred PCI klidová scintigrafie myokardu, která ukázala viabilitu myokardu v povodí infarktové zóny u 69 \% nemocných. Kontrolní scintigrafie po PCI nebyla provedena, ale nemocní, u kterých byla provedena PCI, měli po 4 a 12 měsících méně anginózních obtíži. Později se stávaly anginózní obtíže méně frekventní u obou skupin a po 3 letech nebylo rozdílu v obou skupinách. 
Pravdou ovšem je, že nemocní původně alokovaní do kontrolní neintervenované větve měli později častěji provedenu revaskularizaci mimo protokol a zhruba $\mathrm{u} 10 \% \mathrm{z}$ nich byla provedena mimo protokol i intervence na uzavřené infarktové tepně.

Neočekávaný nález zvýšeného počtu reinfarktů se autoři snaží vysvětlit tím, že časně po kompletním uzávěru tepny se rychle tvoři kolaterály a že tento proces je otevřením tepny zastaven. $\mathrm{V}$ př́ipadě, že dojde k novému spontánnímu uzávěru tepny, je nemocný více disponován ke vzniku infarktu. Toto hypotetické vysvětlení je celkem plauzibilní.

Autoři neudávají, jaké procento nemocných bylo $\mathrm{z}$ celkové populace pacientů po infarktu do studie zařazeno, zdá se však, že šlo o selektované nemocné $\mathrm{s}$ nízkým rizikem. Věk nemocných byl $\mathrm{v}$ průměru 58 let, pouze ve $12 \%$ šlo o recidivu přihody, RIA byla uzavřenou tepnou jen ve $35 \%$ a kumulativní čtyřletá kardiovaskulární mortalita činila $\mathrm{v}$ intervenované skupině $6,3 \%$ a v neintervenované $5,0 \%$. U stabilních pacientů po IM, kteři nemají výraznou reziduálnî ischemii, srdeční slabost nebo elektrickou nestabilitu, tedy nemá smysl bezprostředně po infarktu provádět rekanalizaci tepny, i když se jedná o snížení ejekční frakce pod $50 \%$ anebo o proximální uzávěr tepny.

Výsledky studie dávají jasné poselství pro praxi. U takto definované skupiny nemocných s nízkým rizikem není vhodné provádět pozdní rekanalizaci infarktové tepny. Znamená to tedy, že se nemocní po infarktu (pokud nejsou vyšetřeni v akutní fázi) nemají vůbec angiograficky vyšetřovat? $\mathrm{Ze}$ studie byl vyloučeni nemocní $s$ onemocněním kmene levé věnčité tepny a nemocní $s$ onemocněním tř́i tepen. Asi proto, že se autoři domnivají, že tito nemocní jsou indikováni k revaskularizaci i tehdy, když mají sníženou funkci levé komory. Podle našich zkušeností je takových nemocných v populaci pacientů po infarktu myokardu zhruba $25 \%$ a nedají se odkrýt jinak nežl koronární angiografií. Angiografické vyšetření prováděné $\mathrm{v}$ rámci screeningu $\mathrm{v}$ uvedené studii tedy nesporně mělo určitý výstup. Autoři též udávají, že protokol umožnil PCI u neinfarktové tepny, pokud na ní byly nalezeny významné proximální stenózy. Takových nemocných bylo ve studii $7 \%$ jak v intervenované, tak i v neintervenované skupině. Můžeme jen spekulovat, zda koronární intervence u zmíněných $7 \%$ nemocných, kteři měli významné stenózy, ale neměli významnou ischemii, ovlivnila prognózu nebo nikoliv. Je to však další skupina, kterou nelze odkrýt jinak nežli angiografií. Na otázku, zda se mají nebo nemají rutinně angiograficky vyšetřovat nemocní po infarktu léčeném trombolýzou, u kterých zůstává tepna často uzavřená, tedy studie neodpovídá Nakonec, to je starostí kardiologů tam, kde se infarkt léčí převážně trombolytiky, která zanechávají téměř polovinu infarktových tepen uzavřených.

Podivejme se na poselství ze studie očima českého kardiologa. U nás je na rozdíl od ostatních zemí zavedenou praxí léčit pacienty koronární intervencí Problém se tedy týká pouze nemocných, kteří nebyli angiograficky vyšetřeni bud'to $z$ důvodu pozdního příchodu nebo $z$ důvodů organizačních. Naše doporučení pro indikaci $\mathrm{k}$ angiografii ${ }^{(6)}$ uvádějí, že u asymptomatických nemocných po infarktu myokardu je vyšetření indikováno u stavů po překonaném non-Q -infarktu. U ostatních pacientů po infarktu (v době za 12 hodin po přihodě do propuštění $\mathrm{z}$ nemocnice) pouze $\mathrm{v}$ prípadě vzniku nových bolestí nebo maligních arytmií či kardiogenního šoku; také tehdy, pokud by se zachytila němá ischemie $\mathrm{s}$ depresemi úseku ST hlubšími než $2 \mathrm{~mm}$. Tedy vesměs u nemocných, kteři byli ze studie OAT vyloučeni.

Podíváme-li se však do skutečného života v naší republice pak vidíme, že je běžnou praxí vyšetřit angiograficky na konci hospitalizace nemocné, u kterých nebylo možné provést angiografii a PCI v akutní fázi. Pak je na úvaze kardiologa, zda považuje změny na tepnách za natolik závažné, že doporučí chirurgickou revaskularizaci nebo PCI. Pokud najde uzavřenou infarktovou tepnu, pak se při rozhodování může opřít o výsledky zmíněné studie OAT. Mưže se však o ně opřit i tehdy, když uvažuje o indikaci k chirurgickému výkonu na uzavřené infarktové tepně.

Výsledek může být pro některé $z$ kardiologů zklamáním. Bravurní zvládnutí techniky pozdní rekanalizace tepny totiž nepřineslo klinický užitek. Koronární intervence si stále více nachází své pravé poslání v řešení akutních koronárních syndromů, kde má nezastupitelné místo. Jsou však zřejmě oblasti, ve kterých invazivní kardiolog připomíná muže, který když dostane do ruky pilku vidí náhle spoustu suchých větví. Větví, které nikomu a ničemu nevadí.

\section{LITERATURA}

1. Eagle KA, Goodman SG, Avezum A. Practice variation and missed opportunities for reperfusion in ST-segment-elevation myocardial infarction: findings from the Global Registry of Acute Coronary Events (GRACE). Lancet 2002; 359:373-7.

2. Puma JA, Sketch MH, Thompson TD, et al. Support for the open-artery hypothesis in survivors of acute myocardial infarction: Analysis of 11,228 patients treated with thrombolytic therapy. Am J Cardiol 1999;83: 482-7.

3. Cohen CM, Gensini GF, Maritz F, et al. Prospective evaluation of clinical outcomes after acute ST-elevation myocardial infarction in patients who are ineligible for reperfusion therapy: preliminary results from the TETAMI registry and randomized trial. Circulation 2003; 108 [Suppl III]:III-14-III-21.

4. Hochman JS, Lamas GA, Buller ChE, at al. for the Occluded Artery Trial Investigators Coronary intervention for persistent occlusion after myocardial infarction. New Engl J Med 2006;355:1-13.

5. Džavík V, Bulter ChE, Lamas GA, et al. Randomized trial of percutaneous coronary intervention for subacute infarct-related coronary artery occlusion to achieve long-term patency and improve ventricular function. Circulation 2006;114:2449-57.

6. Doporučení pro provádění koronarografického vyšetření. Cor Vasa 1998;40:K 69-K 73. 